\title{
Analisis Kondisi Sosial Ekonomi Terhadap Migrasi Keluar Kelas Pekerja Jurnal Ecces
}

\author{
Anwar Zainuddin ${ }^{1}$ \\ ${ }^{1}$ Program Studi Manajemen \\ Universitas Patria Artha Makassar \\ Jl. Tun Abdul Razak, Gowa, Sulawesi Selatan \\ E-mail :zainuddin13@gmail.com ${ }^{1}$
}

\section{Abstrak: Analisis Kondisi Sosial Ekonomi Terhadap Migrasi Keluar Kelas Pekerja}

Potensi sektor unggulan pertanian sangat besar di Kabupaten Jeneponto. Sektor yang paling tinggi kontribusinya terhadap perekonomian di daerah ini adalah sektor pertanian. Namun faktanya, justru menunjukkan bahwa banyak masyarakat di daerah ini yang melakukan migrasi keluar dan memilih mencari pekerjaan diluar daerah. Seharusnya hal tersebut tidak terjadi. Penelitian ini bertujuan untuk meneliti apakah tingkat pendapatan perkapita, pendidikan angkatan kerja berpengaruh terhadap migrasi. Penelitian ini menggunakan jenis penelitian kuantitatif, data diolah dengan kebutuhan model yang digunakan. Metode pengambilan sampel dalam penelitian ini menggunakan simple random sampling dengan rumus slovin. Penelitian ini menggunakan sampel penduduk yang berpidah keluar dari Kabupaten Jeneponto. Alat analisis yang digunakan dalam penelitian ini adalah regresi linear berganda dengan migrasi keluar sebagai variabel dependen dan pendapatan perkapita, tingkat pendidikan dan angkatan kerja sebagai variabel independen. Hasil analisis regresi linear berganda bersama-sama menunjukkan bahwa pendapatan perkapita dan angkatan kerja berpengaruh positif terhadap terjadinya migrasi sedangkan tingkat pendidikan berpengaruh negatif. Variabel yang signifikan yaitu variabel pendapatan perkapita dan tingkat pendidikan sedangkan variabel yang tidak signifikan yaitu variabel angkatan kerja. Dan hasil regresi yang telah dilakukan maka diperoleh nilai R-Squae (R2) sebesar 0,766 hal ini dapat disimpulkan bahwa besar persentase variabel migrasi bisa dijelaskan oleh tiga variabel bebas yaitu pendapatan perkapita, tingkat pendidikan dan angkatan kerja sebesar $76,6 \%(0,766)$ sedangkan sisanya dengan nilai $24,4 \%(0,244)$ yang dijelaskan oleh variabel yang tidak masuk dalam penelitian ini. Penelitian ini merekomendasikan kepada pemerintah Kabupaten Jeneponto bahwa untuk mengurangi tingkat migrasi di daerah ini, pemerintah mesti mendorong kebijakan pembukaan kesempatan kerja bagi masyarakat, dengan mengoptimalkan pendidikan dan pelatihan-pelatihan peningkatan skill bagi angkatan kerja, sehingga human capital penduduk semakin tinggi. Dengan demikian, mereka dapat bekerja secara optimal untuk mengelola sumber daya alam dan potensi daerah yang ada.

Kata Kunci: Migrasi, Pendapatan Perkapita, Pendidikan, Angkatan Kerja 


\section{Abstract: Analysis of Socio-Economic Conditions on Migration Exit of Worker Class}

The potential for agricultural sector is very large in Jeneponto Regency. The highest contribution to the economy in this area is the agricultural sector. But in fact, it actually shows that many people in this area are migrating out and choosing to find jobs outside the area. This should not happen. This study aims to examine whether the income per capita level, labor force education has an effect on migration. This study uses a type of quantitative research, data is processed with the needs of the model used. The sampling method in this study, used simple random sampling with the Slovin formula. This study used a sample of residents who came from the district of Jeneponto. The analytical tool used in this study is multiple linear regression with outgoing migration as the dependent variable and per capita income, education level and workforce as independent variables. The results of multiple linear regression analysis together show that per capita income and the workforce have a positive effect on the occurrence of migration while the education level has a negative effect. Significant variables are income per capita variable and education level while non-significant variables are labor force variables. And the results of the regression that have been done then obtained the value of R-Squae (R2) of 0.766 , it can be concluded that the percentage of migration variables can be explained by three independent variables, namely income per capita, education level and workforce of $76.6 \%(0.766)$ while the rest with a value of $24.4 \%(0.244)$ which is explained by variables not included in this study. This study recommends that the Jeneponto Regency government to reduce the level of migration in this area, the government must encourage the opening of employment opportunities for the community, by optimizing education and skills training for the workforce, so that the population's human capital gets higher. Thus, they can work optimally to manage the natural resources and potential of existing regions.

Keywords: Migration, Income Per capita, Education, Labor Force.

\section{PENDAHULUAN / INTRODUCTION}

Potensi sektor unggulan pertanian sangat besar dan cukup melimpah di Kabupaten Jeneponto, termasuk yang ada di Kecamatan Bangkala Barat. Hal itu dibuktikan dengan besarnya kontribusi sektor ini terhadap perekonomian di Kabupaten Jeneponto. Namun, secara faktual justru banyak masyarakat di daerah ini melakukan migrasi, meninggalkan daerahnya untuk mencari pekerjaan di luar daerah, hingga menjadi tenaga kerja di perkotaan. Seharusnya hal tersebut tidak terjadi di di daerah ini. Sektor pertanian dari tahun 2013-2016 meningkat, akan tetapi dari tahun 2017 mengalami penurunan yaitu sebesar 51,69 . Dengan tingginya kontribusi sektor pertanian, maka pertanianlah yang menjadi penggerak perekonomian dan dapat memberdayakan masyarakat yang ada di daerah ini. Namun, hal tersebut berbanding terbalik dengan banyaknya masyarakat yang bermigrasi keluar daerah. Hal tersebut benar-benar kontradiktif dengan apa yang dicapai oleh daerah 
ini. Jenjang pendidikan yang ditamatkan di Kecamatan Bangkala Barat Kabupaten Jeneponto, dimana jenjang pendidikan SD yang ditamatkan sebesar 490 jiwa, jenjang pendidikan SMP yang ditamatkan sebesar 331 jiwa dan jenjang pendidikan SMA sebesar 128 jiwa. Dari beberapa jenjang pendidikan yang telah di jelaskan di atas, maka jenjang pendidikan SD yang paling banyak ditamatkan di Kecamatan Bangkala Barat Kabupaten Jeneponto. Hal ini mengakibatkan rendahnya tingkat pendidikan penduduk yang ada di daerah tersebut, sehingga banyak yang melakukan migrasi dari daerah asal.

Pendapatan perkapita/hari di Kabupaten Jeneponto selalu mengalami peningkatan. Dimana, dari tahun 2013 senilai Rp 15.008, tahun 2014 meningkat menjadi Rp 17.425, di tahun 2015 juga mengalami peningkatan sebesar Rp 19.688, tahun 2016 meningkat sebesar Rp 22.003 dan tahun 2017 meningkat sebesar Rp 24.028. Akan tetapi, masih banyak penduduk yang melakukan migrasi keluar. Angkatan kerja yang ada di Kabupaten Jeneponto dari tahun 2013 sampai dengan tahun 2017 mengalami penurunan. Dimana dari tahun 2013 sebesar 163.723 kemudian, terus menurun sampai tahun 2017 sebesar 149.297 jumlah angkatan kerja. Hal tersebut mengakibatkan banyak penduduk di Kabupaten Jeneponto berpindah keluar, di akibatkan oleh keadaan kondisi sosial ekonomi masing-masing penduduk yang ada di Kabupaten Jeneponto. Misalnya, seseorang berpindah keluar di Kabupaten Jeneponto karena kurangnya lahan pertanian yang dimiliki dan pendapatan yang kurang, mengakibatkan orang tersebut memilih untuk berpindah keluar dari Kabupaten Jeneponto.

Fenomena yang terjadi pada saat ini yaitu migrasi yang berpindah keluar dari Kabupaten Jeneponto. Bisa dilihat bahwa banyaknya penduduk yang berpindah keluar dari Kabupaten Jeneponto ke daerah lain dan nampaknya menjadikan Kota Makassar sebagai salah satu daerah tujuan migrasi. Dimana, Kota Makassar merupakan salah satu ibu kota yang paling berkembang dan banyak menyediakan lapangan kerja. Sebagai tambahan, salah satu daerah di Provinsi Sulawesi Selatan yang banyak melakukan bermigrasi keluar yaitu Kabupaten Jeneponto. Masalah kian menjadi menarik untuk ditelusur, mengapa fenomena tersebut terjadi, dengan berbagai anomali dan kontradiksi yang melatarbelakanginya. 
Data Penduduk yang Pindah Per-Kecamatan di Kabupaten Jeneponto Tahun 2012-2016

\begin{tabular}{clcccccc}
\hline \multirow{2}{*}{ No } & \multirow{2}{*}{ Kecamatan } & \multicolumn{7}{c}{ Mobilitas Penduduk } \\
\cline { 3 - 8 } & 2012 & 2013 & 2014 & 2015 & 2016 & 2017 \\
\hline 1 & Bangkala Barat & 10 & 18 & 81 & 1.203 & 696 & 709 \\
\hline 2 & Tamalatea & 2 & 5 & 24 & 1.461 & 653 & 899 \\
\hline 3 & Binamu & 62 & 71 & 191 & 2.297 & 993 & 1.481 \\
\hline 4 & Batang & 24 & 31 & 120 & 721 & 289 & 445 \\
\hline 5 & Kelara & 2 & 6 & 32 & 866 & 536 & 519 \\
\hline 6 & Bangkala Utara & 0 & 2 & 44 & 580 & 392 & 296 \\
\hline 7 & Bontoramba & 6 & 12 & 51 & 1.228 & 653 & 772 \\
\hline 8 & Turatea & 3 & 9 & 67 & 879 & 505 & 526 \\
\hline 9 & Arungkeke & 11 & 19 & 66 & 537 & 233 & 307 \\
\hline 10 & Rumbia & 0 & 0 & 7 & 694 & 427 & 416 \\
\hline 11 & Tarowang & 4 & 9 & 64 & 911 & 508 & 534 \\
\hline
\end{tabular}

Sumber: Kependudukan dan Catatan Sipil Kabupaten Jeneponto tahun 2012-2017.

\section{TINJAUAN TEORITIK / LITERATURE REVIEW}

\section{Migrasi}

Haris-Todaro dalam Sjafrizal (2014) mengemukakan bahwa perbedaan upah buruh antara desa dan kota, juga merupakan salah satu faktor utama yang menentukan kecenderungan untuk melakukan migrasi. Disamping itu, pola hidup daerah perkotaan yang lebih modern dari daerah pedesaan, juga merupakan daya tarik yang cukup besar untuk pindah. Dalam teori ini perbedaan di kota dan di desa sangat berbeda, dimana di kota terdapat banyak peluang untuk mendapatkan pekerjaan dan upah yang lebih tinggi, sedangkan di desa peluang pekerjaan terbatas dan upah yang didapatkan tidak menentu dan hal ini menyebabkan banyak masyarakat keluar untuk bermigrasi.

Namun berbeda dengan pandangan Ravenstein dan Hugo dalam Mulyadi S. (2014) mengemukakan bahwa undang-undang yang tidak baik, iklim yang tidak menguntungkan dan lingkungan masyarakat yang tidak mendukung dari dulu sampai sekarang, merupakan faktor-faktor yang menimbulkan arus migrasi. Teori ini dapat disimpulkan bahwa dengan 
iklim dan lingkungan yang tidak baik di daerah asal, serta dorongan untuk memperbaiki perekonomian keluarga mengakibatkan banyak penduduk yang melakukan migrasi. Lingkungan yang terdapat di daerah tujuan mendorong orang pindah karena adanya rasa superior di tempat yang baru, terutama untuk mendapatkan lapangan pekerjaan, pendapatan, pendidikan dan kehidupan yang lebih menyenangkan. Sedangkan daerah di lingkungan asal, mendorong orang untuk pindah karena adanya tekanan-tekanan, seperti berkurangnya sumber daya alam, menyempitnya lapangan pekerjaan, bencana alam dan tekanan-tekanan di bidang sosial, politik dan agama. Hal yang mendorong orang untuk pindah, bukan hanya ditentukan oleh faktor-faktor nyata yang terdapat di daerah asal. Kepekaan pribadi, kecerdasan, kesadaran tentang kondisi setempat. Sedangkan pengetahuan tentang keadaan di tempat tujuan, tergantung kepada hubungan seseorang atau berdasarkan berbagai informasi yang diperolehnya. Disisi lain, perpindahan penduduk, baik yang bersifat permanen maupun tidak permanen, merupakan suatu respon terhadap tekanan dari lingkungan, baik dalam bentuk ekonomi, sosial maupun demografi. Teori ini menekankan bahwa adanya tekanan dari lingkungan mengakibatkan banyak penduduk yang pindah keluar dari daerah asal, baik secara permanen atau tidak permanen. Migrasi sering kali dianalisis berdasarkan pada faktor pendorong (pust factor) dan faktor penarik (Pull Factor) yang menyebabkan terjadinya perpindahan penduduk tersebut. Migrasi dipengaruhi oleh tarikan ketersediaan lapangan kerja dan tingkat upah yang cukup tinggi pada wilayah yang lebih maju. Sedangkan dorongan melakukan migrasi muncul dari tekanan upah yang lebih rendah dan keterbatasan penyediaan lapangan kerja, pada wilayah yang relatif kurang maju.

Maboqunye dalam Mulyadi (2014) mengemukakan bahwa migrasi dari pedesaan ke perkotaan, tidak hanya berkaitan dengan lingkungan, daya tarik daerah tujuan dan daya dorong daerah asal (push and pull factors) saja, tetapi lebih dari itu. Hubungan yang dibentuk lebih bersifat kompleks yang membentuk suatu sistem yang bersifat umum, dimana efek perubahan dari suatu bagian sistem akan memengaruhi keseluruhan dari sistem tersebut. Kondisi sosial ekonomi yang ada di daerah asal, tidak memungkinkan untuk memenuhi kebutuhan seseorang menyebabkan orang tersebut ingin pergi ke daerah lain yang dapat memenuhi kebutuhan tersebut. Sedangkan tiap individu mempunyai kebutuhan yang berbeda, maka penilaian terhadap daerah asal dari masing-masing individu di masyarakat tersebut berbeda-beda, sehingga proses pengambilan keputusan untuk pindah (mobilitas) dari masing-masing individu berbeda pula. 


\section{Pendapatan}

Adam Smith dan David Ricardo dalam Todaro (2009) mengemukakan bahwa pendapatan digolongkan dalam tiga kelas sosial utama: pekerja, pemilik modal, dan tanah. Ketiganya menentukan faktor produksi, yaitu tenaga kerja, modal, dan tanah. Teori ini juga meramalkan bahwa begitu masyarakata maju, dan relatif lebih baik keadaannya dan para kapitalis (pemilik modal) menjadi relatif lebih buruk keadaanya.

Sedangkan menurut Pareto dalam Tarigan (2009) yang mengemukakan bahwa distribusi pendapatan berdasarkan besarnya (size distribution of income), yaitu distribusi pendapatan diantara rumah tangga yang berbeda, tanpa mengacu pada sumber-sumber pendapatan atau kelas sosialnya dan ketidakmerataan distribusi pendapatan cukup besar disemua negara. Pendapatan yaitu hasil pengurangan dari total output dengan total input.

Menurut Milton Friedman dalam Deliarnov (2005) yang mencoba menarik kesimpulan bahwa pendapatan suatu rumah tangga adalah jumlah gaji, laba, penyebaran bunga, sewa dan bentuk penghasilan lain yang diterima oleh suatu rumah tangga pada periode waktu tertentu. Hal ini, berarti bahwa pendapatan suatu rumah tangga memiliki waktu tertentu. Terkait dengan pendapatan, masyarakat dapat digolongkan menjadi dua yaitu pendapatan permanen (permanent income) dan pendapatan sementara (transitory income). Pengertian dari pendapatan permanen adalah pendapatan yang selalu diterimah pada setiap periode tertentu dan dapat diperkirakan sebelumnya. Dan pendapatan yang diperoleh dari semua faktor yang menentukan kekayaan seseorang. Todaro (2000) menyimpulkan bahwa keputusan untuk bermigrasi tergantung pada selisih antara tingkat pendapatan yang diharapkan di kota dan tingkat pendapatan aktual di desa.

Namun berbeda dengan pandangan Salvatore (1996) dan Sukirno (1995) yang mengemukakan bahwa ada cukup banyak keuntungan ekonomi dari migrasi. Bagi para pekerja, tingkat pendapatan di tempat baru lebih tinggi dari pada yang mereka peroleh dari tempat asalnya. Dengan pendapatan yang lebih tinggi itu mereka akan memperoleh standar hidup yang lebih baik. Mereka juga dapat menyediakan pendidikan, peluang kerja serta masa depan yang lebih baik untuk anak-anaknya. Pendapatan pada dasarnya merupakan balas jasa yang diterima pemilik faktor produksi atas pengorbanannya dalam proses 
Anwar Zainuddin, Analisis Kondisi Sosial Ekonomi Terhadap Migrasi...

produksi. Masing-masing dari faktor produksi seperti, tanah akan memperoleh balas jasa dalam bentuk sewa tanah, tenaga kerja akan memperoleh balas jasa berupa upah/gaji, modal akan memperoleh balas jasa dalam bentuk bunga modal, serta keahlian termasuk para enterpreneur akan memperoleh balas jasa dalam bentuk laba.

\section{Angkatan Kerja}

David Ricardo dalam Arieboz (2013) mengemukakan bahwa faktor, tenaga kerja adalah hal yang paling penting dalam pencapaian kemakmuran suatu negara. Ia juga melihat bahwa dengan bertambahnya penduduk, maka tingkat penghasilan atau upah itu tidak cukup lagi menyokong pemenuhan kebutuhan mereka. Seiring dengan pertambahan penduduk, harga tanah pun melonjak dan hal ini akan menurunkan besarnya keuntungan yang diperoleh dari sektor produksi. Pertumbuhan modal pun akan terhambat dan akan menurunkan pola pertumbuhan ekonomi. Sedangkan Jumlah penduduk yang semakin tinggi dan permintaan akan tanah semakin tinggi, namun jumlah tanah yang sangat terbatas mengakibatkan jumlah tenaga kerja menurun.

Namun berbeda dengan pandangan dengan Adam Smith dalam Deliarnov (2005) yang menggarisbawahi bahwa peningkatan terbesar dalam produktifitas tenaga kerja, dan sebagian besar keterampilan, ketangkasan, dan penilaian dimana saja diarahkan atau diterapkan adalah efek dari pembagian kerja. Pembagian kerja akan mendorong spesialisasi, orang akan memilih mengerjakan yang terbaik sesuai dengan bakat dan kemampuan masing-masing. Teori ini menjelaskan bahwa bukanlah jumlah tenaga kerja yang menentukan tingkat produksi, akan tetapi sangat tergantung dari spesialisasi atau pembagian kerja yang dimiliki. Semakain tinggi tingkat spesialisasi tenaga kerja, maka tingkat keahlian tenaga kerja semakin banyak, sehingga produksi akan ditentukan oleh spesialisasi.

Sedangkan menurut Keynes dalam Deliarnov (2005) bahwa produktivitas marginal tenaga kerja (marginal value of labor), yang dijadikan sebagai patokan oleh pengusaha dalam mempekerjakan tenaga kerja akan turun. Jika penurunan dalam harga-harga tidak begitu besar, maka kurva nilai produktivitasnya hanya turun sedikit. Meskipun demikian, jumlah tenaga kerja yang bertambah tetap saja lebih kecil dari jumlah tenaga kerja yang ditawarkan. Lebih parah lagi kalau harga-harga turun drastis, maka kurva nilai produktivitas marginal dari tenaga kerja juga turun drastis dimana jumlah tenaga kerja yang tertampung 
menjadi semakin kecil dan pengangguran menjadi semakin bertambah luas. Dalam teori ini produktivitas tenaga kerja yang harus diutamakan bukan pada jumlah tenaga kerja.

\section{METODE PENELITIAN / METHODS}

Metode penelitian yang digunakan dalam penelitian ini adalah metode deskriptif kuantitatif. Dimana penelitian kuantitatif ini merupakan penelitian yang dilakukan dengan mengumpulkan data yang berupa angka, atau data berupa kata-kata atau kalimat yang dikonversi menjadi data yang berbentuk angka dengan perhitungan statistik. Dengan menggunakan penelitian kuantitatif penulis ingin mengetahui apakah tingkat pendapatan, tingkat pendidikan dan angkatan kerja sangat berpengaruh terhadap terjadinya migrasi. Penelitian ini dilakukan di Kabupaten Jeneponto. karena peneliti ingin melihat pendapatan perkapita, jenjang pendidikan yang ditamatkan, dan angkatan kerja di Kabupaten Jeneponto yang melakukan migrasi. Adapun jangka waktu untuk melakukan penelitian ini yaitu selama 1-6 bulan.

Jenis data yang dikumpulkan terdiri atas dua yaitu data primer dan data sekunder. Data Primer merupakan data yang diperoleh langsung dari lapangan baik melalui wawancara dengan pihak terkait, koesioner dan observasi langsung sedangkan Data sekunder merupakan data yang telah diolah dan diperoleh dari Badan Pusat Statistik atau data dari pihak-pihak terkait, seperti data mengenai gambaran umum lokasi penelitian dan data sekunder memanfaatkan data yang dihasilkan dari survey, misalnya data hasil sensus penduduk. Teknik sampel yang digunakan pada penelitian ini adalah Simple Random Sampling, yang dimaksud dengan Simple Random Sampling (sampel acak sederhana) merupakan teknik pengambilan sampel yang dilakukan secara acak tanpa memerhatikan strata yang ada dalam populasi tersebut. Populasi yang ada di objek penelitian ini adalah masyaraka yang berpindah keluar dari Kabupaten Jeneponto khususnya di Kecamatan Bangkala Barat. Dimana, Kecamatan Bangkala Barat adalah salah satu Kecamatan yang paling banyak penduduknya bermigrasi dalam kriteria tersebut sebanyak 696 . Penelitian ini menggunakan penentuan sampel menggunakan rumus slovin dan diperoleh 87 responden. Metode analisis yang digunakan untuk menguji hipotesi adalah regresi linear berganda dengan alat analisis SPSS (Software Statistik Program For Social Science) sebagai berikut: 
$Y=\beta 0+\beta 1 X 1+\beta 2 X 2+\beta 3 X 3+\mu$

Keterangan:

$$
\begin{aligned}
& \mathrm{Y}=\text { Migrasi } \\
& \mathrm{X} 1=\text { Pendapatan Perkapita } \\
& \mathrm{X} 2=\text { Pendidikan yang di tamatkan } \\
& \mathrm{X} 3=\text { Angkatan Kerja } \\
& \beta 0=\text { Konstanta } \\
& \beta 1-\beta 3=\text { Parameter } \\
& \mu \quad=\text { Error Term }
\end{aligned}
$$

\section{HASIL DAN PEMBAHASAN / DISCUSSION}

\section{Hasil Uji Normalitas Data}

Uji normalitas bertujuan untuk menguji apakah dalam model regresi, variabel terikat dan variabel bebas keduanya mempunyai distribusi normal atau tidak. Salah satu metode untuk mengetahui normalitas adalah dengan menggunakan metode analisis grafik, baik dengan melihat grafik secara histogram ataupun dengan melihat secara Normal Probability Plot. Normalitas data dapat dilihat dari penyebaran data (titik) pada sumbu diagonal pada grafik normal P-Plot atau dengan melihat histogram dari residualnya.

\section{Gambar 1 Histogram}

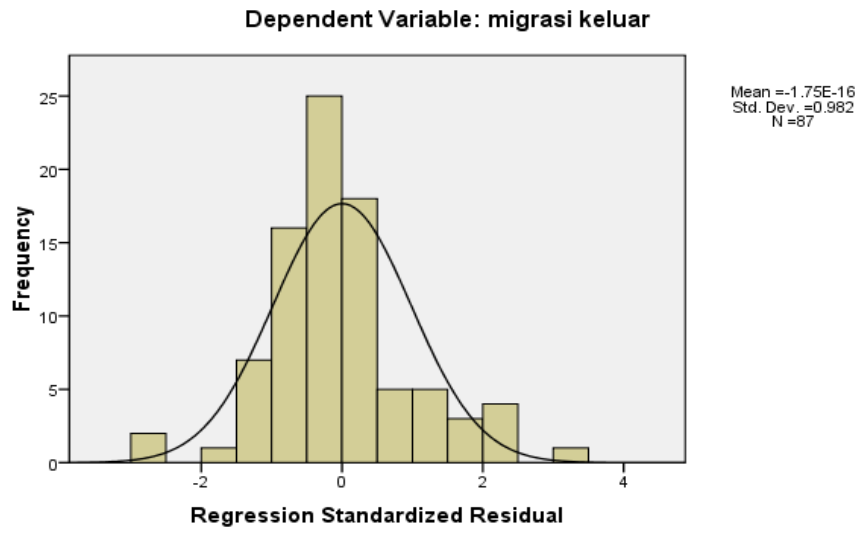




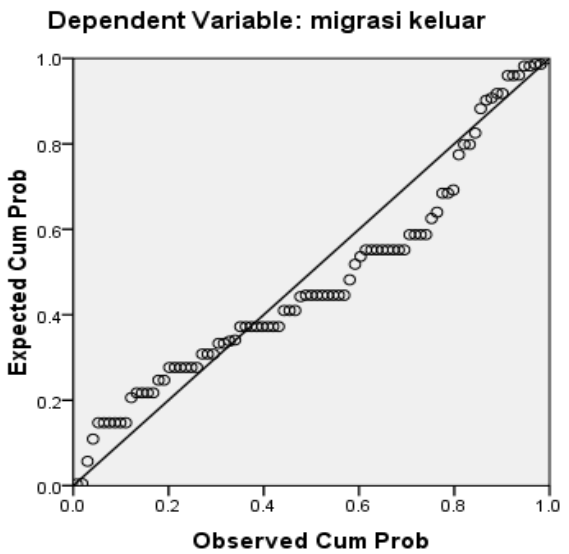

Berdasarkan gambar tersebut maka dapat dijelaskan bahwa normal Probability Plot di atas menunjukkan bahwa data menyebar disekitar garis diagonal dan mengikuti arah garis diagonal dan menunjukkan pola distribusi normal, sehingga dapat disimpulkan bahwa asumsi normalitas telah terpenuhi.

\section{Hasil Uji Multikolinearitas}

Berdasarkan tabel yang ada, maka dapat diketahui nilai VIF untuk masing-masing variabel pendapatan, pendidikan dan angkatan kerja nilai VIF nya <10 dan nilai toleransinya $>0,10$ sehingga model dinyatakan tidak terjadi multikolinearitas.

Tabel 1. Uji Multikolinieritas

\section{Coefficients $^{a}$}

\section{Collinearity Statistics}

\begin{tabular}{lllr}
\multicolumn{2}{c}{ Model } & Tolerance & VIF \\
\hline & (Constant) & & 1.464 \\
\cline { 2 - 4 } 1 & Pendapatan & .683 & 4.768 \\
\cline { 2 - 4 } & Pendidikan & .210 & 4.866 \\
\cline { 2 - 4 } & angkatan kerja & .206 &
\end{tabular}


Coefficients $^{\mathrm{a}}$

Collinearity Statistics

\begin{tabular}{lllr}
\multicolumn{2}{c}{ Model } & Tolerance & VIF \\
\hline & (Constant) & & \\
\cline { 2 - 4 } 1 & Pendapatan & .683 & 1.464 \\
& Pendidikan & .210 & 4.768 \\
\cline { 2 - 5 } & angkatan kerja & .206 & 4.866
\end{tabular}

Sumber: Output SPSS 16 data diolah, 2018.

\section{Hasil Uji Autokolerasi}

Pada tabel uji autokorelasi menunjukkan bahwa nilai Durbin Watson untuk penelitian ini sebesar 2,331 dengan pengujian DW > dU. Dengan menlihat tabel DW maka diperoleh nilai DW sebesar 2,408 lebih besar dari nilai dU sebesar 1,7232. Maka DW $>\mathrm{dU}=2,331>$ 1,7232. Maka dapat disimpulkan bahwa koefisien bebas dari gangguan autokorelasi.

Tabel 2 Uji Autokorelasi

Model Summary

\begin{tabular}{|c|c|c|c|c|c|}
\hline Model & $\mathrm{R}$ & R Square & $\begin{array}{l}\text { Adjusted R } \\
\text { Square }\end{array}$ & $\begin{array}{l}\text { Std. Error of the } \\
\text { Estimate }\end{array}$ & Durbin-Watson \\
\hline 1 & $.875^{\mathrm{a}}$ & .765 & .757 & .247 & 2.331 \\
\hline
\end{tabular}

Sumber: Output SPSS 16 data diolah, 2018.

\section{Hasil Uji Heteroskedastisitas}

Dari gambar Scatter plot tersebut, terlihat titik-titik menyebar secara acak dan tidak membentuk suatu pola tertentu yang jelas, serta tersebar baik diatas maupun dibawah angka 0 pada sumbu Y. hal ini berarti tidak terjadi heteroskedastisitas pada model regresi, sehingga model regresi layak dipakai untuk memprediksi pengaruh variabel berdasarkan masukan variabel independennya. 
Gambar 3 Uji Heterokedastisitas

Scatterplot

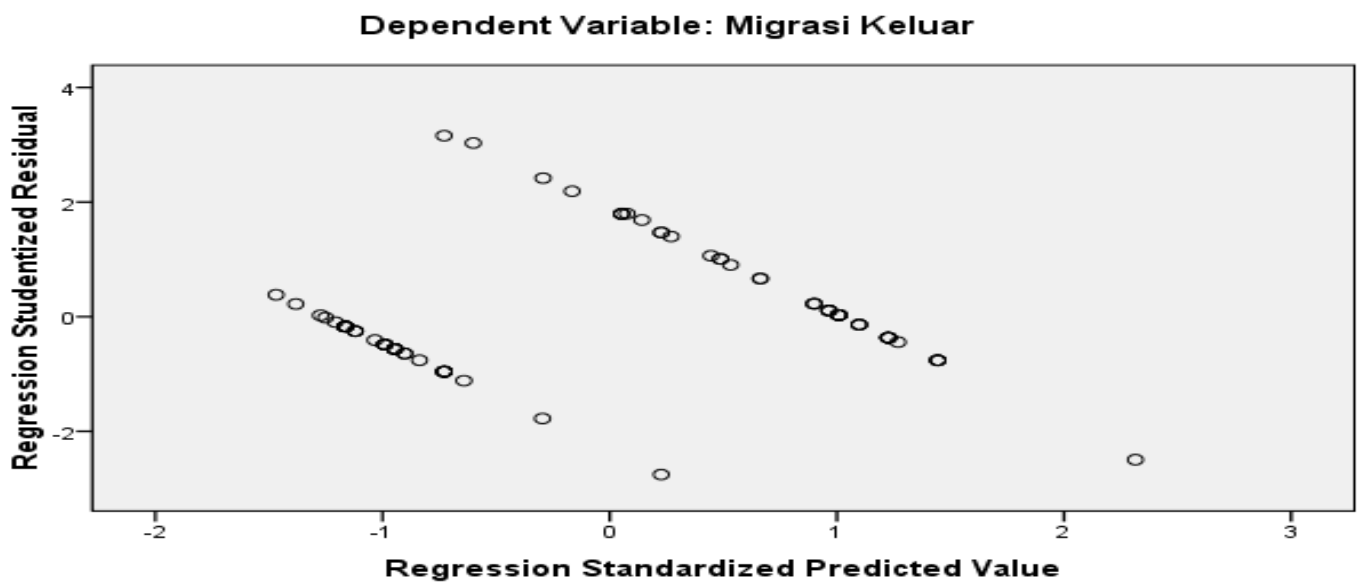

Sumber: Output SPSS 16 data diolah, 2018.

\section{Hasil Uji Simultan (Uji F)}

Tabel 3 Hasil Uji Simultan (Uji F)

ANOVA $^{\text {b }}$

\begin{tabular}{|c|c|c|c|c|c|c|}
\hline Model & & Sum of Squares & $d f$ & Mean Square & $F$ & Sig. \\
\hline \multirow{3}{*}{1} & Regression & 16.467 & 3 & 5.489 & 90.200 & $.000^{\mathrm{a}}$ \\
\hline & Residual & 5.051 & 83 & .061 & & \\
\hline & Total & 21.517 & 86 & & & \\
\hline
\end{tabular}

Sumber: Output SPSS 16 data diolah, 2018.

Dari hasil regresi diperoleh $\mathrm{F}$ sebesar 90.200 dengan signifikan sebesar 0,000 artinya bahwa analisis ini signifikan dengan tingkat signifikansi kurang dari 5\% maka $\mathrm{HO}$ ditolak dan Ha di terima. Dengan kata lain secara bersama-sama variabel pendapatan (X1), tingkat pendidikan (X2), angkatan kerja (X3) berpengaruh terhadap migrasi di Kabupaten Jeneponto $(Y)$.

\section{Hasil Uji Parsial (Uji t)}

Tabel 4 Hasil Uji Parsial (Uji t) 


\section{Coefficients $^{\mathrm{a}}$}

Standardized

Unstandardized Coefficients Coefficients

\begin{tabular}{|c|c|c|c|c|c|}
\hline Model & B & Std. Error & Beta & $\mathrm{t}$ & Sig. \\
\hline (Constant) & 1.984 & .158 & & 12.587 & .000 \\
\hline pendapatan & $2.255 \mathrm{E}-7$ & .000 & .408 & 6.336 & .000 \\
\hline pendidikan & -.207 & .022 & -1.091 & -9.391 & .000 \\
\hline $\begin{array}{l}\text { angkatan } \\
\text { kerja }\end{array}$ & .079 & .118 & .079 & 670 & .505 \\
\hline
\end{tabular}

Sumber: Output SPSS 16 data diolah, 2018.

Dari hasil analisis regresi linear berganda diperoleh hasil yaitu Variabel pendapatan responden (X1) memiliki nilai signifikan sebesar 0.000 , nilai ini menunjukkan bahwa nilai signifikan lebih kecil dari level of significance $(a=0,05)$. Jadi, hipotesis yang menyatakan bahwa pendapatan responden berpengaruh signifikan terhadap migrasi di Kabupaten Jeneponto. Variabel tingkat pendidikan (X2) memiliki nilai signifikan sebesar 0.000 nilai ini menunjukkan bahwa nilai signifikan lebih kecil dari level of significance $(a=0,05)$. Jadi hipotesis yang menyatakan bahwa tingkat pendidikan berpengaruh signifikan terhadap migrasi di Kabupaten Jeneponto terbukti kebenarannya. Variabel angkatan kerja (X3) memiliki nilai tidak signifikan sebesar 0,505, nilai ini menunjukkan bahwa nilai tidak signifikan lebih besar dari level of significance $(a=0,05)$. Jadi, hipotesis yang menyatakan bahwa angkatan kerja tidak berpengaruh signifikan terhadap migrasi keluar di Kabupaten Jeneponto.

\section{Hasil Uji Determinasi $\left(\mathbf{R}^{2}\right)$}

Dari hasil analisis diketahui bahwa nilai koefisien $\left(R^{2}\right)$ sebesar 0.765 sesuai dengan kriteria pengujian $\mathrm{R}^{2}=0.766$ terletak diantara 0 sampai dengan 1 , dengan demikian pendapatan (X1), tingkat pendidikan (X2), angkatan kerja (X3) mempunyai pengaruh yang sedang terhadap terjadinya migrasi. Data tersebut juga menunjukkan bahwa variabel bebas mampu menjelaskan persentase sumbangan terhadap naik turunnya migrasi sebesar $76,5 \%$ sedangkan sisanya $23,5 \%$ perubahan besarnya migrasi disebabkan oleh faktor lain di luar penelitian ini.

Tabel 5 Koefisien Determinasi $\left(R^{2}\right)$

Model Summary 


\begin{tabular}{lrrrr} 
Model & R & R Square & Adjusted R Square & \multicolumn{2}{c}{ Durbin-Watson } \\
\hline 1 & $.875^{\mathrm{a}}$ & .765 & .757 & 2.331
\end{tabular}

Sumber: Output SPSS 16 data diolah, 2018.

\section{Analisis Regresi Linear Berganda}

Berdasarkan pengolahan data penelitian yang telah dikumpulkan melalui kuesioner, baik untuk variabel terikat yaitu Migrasi $(Y)$ maupun variabel bebas yang meliputi Pendapatan Perkapita (X1), Pendidikan (X2) dan Angkatan Kerja (X3) maka diperoleh hasil perhitungan regresi linear berganda sebagai berikut:

Tabel 6 Rekapitulasi Hasil Uji Regresi

Coefficients $^{\mathrm{a}}$

\begin{tabular}{|c|c|c|c|c|c|c|}
\hline \multirow{2}{*}{\multicolumn{2}{|c|}{ Model }} & \multicolumn{2}{|c|}{ Unstandardized Coefficients } & \multirow{2}{*}{$\begin{array}{c}\begin{array}{c}\text { Standardize } \\
\mathrm{d} \\
\text { Coefficients }\end{array} \\
\text { Beta }\end{array}$} & \multirow[b]{2}{*}{$\mathrm{t}$} & \multirow[b]{2}{*}{ Sig. } \\
\hline & & $\mathrm{B}$ & Std. Error & & & \\
\hline \multirow[t]{4}{*}{1} & (Constant) & 1.984 & .158 & & $\begin{array}{r}12.58 \\
7\end{array}$ & .000 \\
\hline & pendapatan & $2.255 \mathrm{E}-7$ & .000 & .408 & 6.336 & .000 \\
\hline & pendidikan & -.207 & .022 & -1.091 & -9.391 & .000 \\
\hline & $\begin{array}{l}\text { angkatan } \\
\text { kerja }\end{array}$ & .079 & .118 & .079 & .670 & .505 \\
\hline
\end{tabular}

Sumber: Output SPSS 16 data diolah, 2018.

Dependent Variable: migrasi keluar

Berdasarkan tabel tersebut diperoleh persamaan regresi sebagai berikut:

$$
\begin{aligned}
& Y=\beta_{0}+\beta_{1} X_{1}+\beta_{2} X_{2}+\beta_{3} X_{3}+e \\
& Y=2.021+1.906 X 1-0,203 \times 2+0.077 \times 3+e
\end{aligned}
$$

\section{Pengaruh Pendapatan Terhadap Migrasi Keluar}


Berdasarkan hasil uji regresi dapat diketahui bahwa pendapatan responden $\left(\beta_{1}\right)$ sebesar 2.255 dengan nilai signifikan 0.000 . koefisien regresi yang bernilai positif menunjukkan bahwa pendapatan akan meningkatkan migrasi dengan asumsi variabel yang lain dianggap konstan (tetap). Pendapatan merupakan salah satu hasil kerja atau usaha yang dilakukan seseorang untuk memenuhi kehidupan sehari-hari. maka dari itu, semakin tinggi pendapatan seseorang maka kehidupan sehari-harinya terpenuhi.

Hasil ini sejalan yang diteliti oleh ayu wulan puspitasari (2010:80) dengan penelitian analisis faktor-faktor yang mempengaruhi minat migrasi sirkuler ke Kabupaten Semarang dengan hasil yaitu memiliki koefisien sebesar 0,000 dengan nilai wald 16,329 dengan signifikasi 0,01 maka variabel ini menunjukkan pengaruh yang signifikan untuk melakukan migrasi sirkuler.

Hasil penelitian ini tidak sejalan dengan penelitian yang dilakukan oleh Reni dkk (2016:81) dengan penelitian analisis keputusan bermigrasi tenaga kerja asal Kabupaten Ogan Ilir ke Malaysia dengan hasil yaitu tingkat pendapatan bertanda positif dan tidak signifikan, artinya bahwa tinggi rendahnya pendapatan responden di daerah asal tidak mempengaruhi peluang untuk mengambil keputusan bermigrasi.

Pengaruh tingkat pendapatan terhadap terjadinya migrasi di Kabupaten Jeneponto. Ini sejalan dengan yang diteliti oleh Abet (2014) dengan penelitian analisis pendapatan dan angkatan kerja terhadap urabanisasi di Kota Bengkulu dengan hasilnya yaitu nilai probabilitas 0,006019 dengan tingkat kepercayaan 99\% maka nilai ini lebih kecil dari $X=0,05$. Keadaan ini menunjukkan bahwa pendapatan perkapita berpengaruh secara signifikan terhadap tingkat urbanisasi di Kota Bengkulu.

\section{Pengaruh Tingkat Pendidikan Terhadap Migrasi Keluar}

Berdasarkan hasil uji regresi dapat diketahui bahwa tingkat pendidikan responden $\left(\beta_{2}\right)$ sebesar -0.207 dengan nilai signifikan 0.000 . Koefisien regresi yang bernilai negatif menunjukkan bahwa peningkatan tingkat pendidikan akan menurunkan migrasi dengan asumsi variabel yang lain dianggap konstan (tetap). Tingkat pendidikan merupakan wadah untuk menimbah ilmu dan meningkatkan kualitas hidup seseorang. Maka dari itu, semakin tinggi tingkat pendidikan seseorang, maka pengetahuan dan keahlian juga akan meningkat sehingga akan mendorong penigkatan produktifitas kerjanya.

Hasil penelitian ini sejalan yang diteliti oleh Farhan Anwar dkk (2016:12) dengan penelitian, faktor penentu keputusan migrasi ke papua pada masyarakat Desa Jaddih dengan hasilnya yaitu variabel pendidikan memiliki koefisien sebesar -0.746 dengan nilai signifikasi 0.05 . bila menggunakan taraf signifikan a sebesar $10 \%$ maka variabel pendidikan 
menunjukkan pengaruh yang signifikan terhadap migrasi. Artinya tingkat pendidikan sangat berpengaruh terhadap keputusan bermigrasi ke papua.

Hasil penelitian Ini tidak sejalan dengan penelitian yang dilakukan ayu wulan puspitasari (2010:83) dengan penelitian analisis faktor-faktor yang mempengaruhi minat migrasi sirkuler ke Kabupaten Semarang yang mengemukakan bahwa tingkat pendidikan memiliki koefisien sebesar 0,304 dengan nilai wald 2,737 dengan signifikansi 0,098 bila menggunakan taraf signifikansi 0,05 maka variabel ini tidak menunjukkan pengaruh yang signifikan untuk melakukan migrasi sirkuler.

Pengaruh tingkat pendidikan terhadap terjadinya migrasi di Kabupaten Jeneponto. Ini sejalan yang diteliti oleh Putu Ayu (2010) dengan penelitian analisis pengaruh upah, lama migrasi, umur dan tingkat pendidikan terhadap minat migrasi sirkuler penduduk salatiga ke Kota Semarang dengan hasilnya yaitu semakin tinggi tingkat pendidikan responden maka minat untuk melakukan migrasi sirkuler makin besar. Pada P-value 0,027 dan koefisien 1,152 menunjukkan variabel tingkat pendidikan berpengaruh positif dan signifikan. Artinya, tingkat pendidikan sangat berpengaruh terhadap minat migrasi sirkuler penduduk salatiga ke Kota Semarang.

\section{Pengaruh Angkatan Kerja Terhadap Migrasi Keluar}

Berdasarkan hasil uji regresi dapat diketahui bahwa angkatan kerja $\left(\beta_{3}\right)$ sebesar 0.079 dengan nilai signifikan 0.505 . koefisien regresi yang bernilai positif dan tidak signifikan menunjukkan bahwa angkatan kerja cenderung lebih tinggi di luar daerah dibandingkan di daerah asal dengan asumsi variabel yang lain dianggap konstan (tetap). Hal ini menunjukkan bahwa dengan tingginya angkatan kerja dil luar daerah maka, hal tersebut tidak berpengaruh terhadap terjadinya migrasi di Kabupaten Jeneponto.

Hasil penelitian ini sejalan yang diteliti oleh Farhan dkk (2016) dengan penelitian faktor penentu keputusan migrasi ke Papua pada masyarakat Desa Jaddih yang mengemukakan bahwa status pekerjaan memiliki koefisien sebesar -2,749 dengan nilai signifikasi 0,038. Hal ini menunjukkan bahwa faktor status pekerjaan tidak berpengaruh terhadap keputusan bermigrasi.

Ini tidak sejalan dengan penelitian yang dilakukan oleh Abet Nego Imanuel S (2014:59) dengan penelitian analisis pendapatan dan angkatan kerja terhadap urabanisasi di Kota Bengkulu yang mengemukakan bahwa semakin besar jumlah penduduk usia kerja 
maka semakin besar pula jumlah angkatan kerja. Tingkat partisipasi angkatan kerja dipengaruhi oleh berbagai faktor yaitu faktor umur, status perkawinan, tingkat pendidikan, daerah tempat tinggal dan pendapatan. Dari faktor-faktor yang mempengaruhi tingkat partisipasi angkatan kerja terdapat faktor daerah tempat tinggal dan pendapatan. Tingkat pendapatan yang bekerja di desa dan yang bekerja di kota sangat berbeda dan tingkat pendapatan di kota jauh lebih tinggi dibandingkan tingkat pendapatan di desa.

\section{KESIMPULAN / CONCLUSION}

Berdasarkan hasil analisis dan data yang diperoleh dari penelitian analisis pengaruh kondisi sosial ekonomi terhadap terjadinya migrasi di Kabupaten Jeneponto, maka dapat diambil kesimpulan bahwa pendapatan perkapita berpengaruh positif dan signifikan terhadap terjadinya migrasi di Kabupaten Jeneponto. Pendapatan perkapita yang di dapatkan di luar daerah lebih tinggi, maka tingkat migrasi dari Kabupaten Jeneponto semakin tinggi. Tingkat pendidikan berpengaruh negatif dan signifikan terhadap terjadinya migrasi di Kabupaten Jeneponto. Semakin tinggi tingkat pendidikan seseorang, maka tingkat migrasi di Kabupaten Jeneponto juga semakin tinggi. Angkatan kerja berpengaruh positif dan tidak signifikan terhadap terjadinya migrasi di Kabupaten Jeneponto. Peningkatan angkatan kerja, tidak berpengaruh terhadap tingkat migrasi di Kabupaten Jeneponto. Berdasarkan kesimpulan di atas, sebagai masukan dan saran terhadap pemerintah Kabupaten Jeneponto dalam rangka mengurangi tingkat migrasi di Kabupaten Jeneponto yaitu Pemerintah Kabupaten Jeneponto mesti mendorong kebijakan untuk membuka kesempatan kerja bagi masyarakat dengan mengoptimalkan pendidikan dan pelatihanpelatihan peningkatan skill bagi angkatan kerja, sehingga human capital penduduk Jeneponto semakin tinggi. Dengan demikian, mereka dapat bekerja secara optimal untuk mengelola sumber daya alam dan Potensi daerah yang ada di Kabupaten Jeneponto serta mengupayakan peningkatan pendapatan terhadap tenaga kerja di Kabupaten jeneponto, sehingga tingkat migrasi dapat terkendali.

\section{DAFTAR PUSTAKA / REFERENCES}

Abet, Nego Imanuel. 2014. Analisis Pendapatan Dan Angkatan Kerja Terhadap Urbanisasi di Kota Bengkulu.

Anwar Farhan, dkk. 2016. Faktor Penentu Keputusan Migrasi Ke Papua Pada Masyarakat Desa Jaddih. Jurnal Pamator.

Arieboz. http://www.ekonomic-holic.com/Tokoh-Ekonomi-David-Ricardo-html, 2013. 
Deliarnov. 2005. Perkembangan Pemikiran Ekonomi, Edisi Revisi 4, Jakarta: PT Raja Grafindo Persada.

Puspitasari, Ayu Wulan. 2010. Analisis Faktor-Faktor Yang Mempengaruhi Minat Migrasi Sirkuler Ke Kabupaten Semarang.

Reni, Nurlina Tarmizi, Maryadi. 2016. Analisis Keputusan Bermigrasi Tenaga Kerja Asal Kabupaten Ogan Ilir Ke Malaysia. Jurnal Ekonomi.

S Mulyadi. 2014. Ekonomi Sumber Daya Manusia. Edisi Revisi. Jakarta: Rajawali Pers.

Sanis, Putu Ayu. 2010. Analisis Pengaruh Upah, Lama Migrasi, Umur Dan Tingkat Pendidikan Terhadap Minat Migrasi Sirkuler Penduduk Salatiga Ke Kota Semarang.

Sjafrizal. 2014. Ekonomi Wilayah Dan Perkotaan. Edisi Satu. Jakarta: Rajawali Pers.

Tarigan, Robinston. 2009. Ekonomi Regional Teori dan Aplikasi. Edisi Revisi. Jakarta: Bumi Aksara.

Todaro Michael P., Stephen C. Smith. 2009. Pembangunan Ekonomi. Edisi Kesebelas. Jakarta: Erlangga. 